\title{
T and B lymphocytes in sarcoidosis: a clinical correlation
}

\author{
J . M . C UMM I S K Y ${ }^{1}, H$. M c L A U G H L I , \\ a n d P. K E E L A N \\ Mater Misericordiae Hospital, Dublin 7 and Department of Pathology, \\ University College, Dublin 2
}

\begin{abstract}
Cummiskey, J. M., McLaughlin, H., and Keelan, P. (1976). Thorax, 31, 665-668. T and B lymphocytes in sarcoidosis: a clinical correlation. Immunological abnormalities in sarcoidosis have been previously described. Cutaneous anergy to a wide variety of antigens first prompted the suggestion that the underlying defect may be of importance in the aetiology or pathogenesis of the disorder. The thymus derived lymphocytes appear to be particularly affected, and both quantitative and qualitative in vitro defects have been described in these cells in sarcoidosis patients. We have quantitatively investigated $\mathrm{T}$ and B cells in a series of 52 sarcoidosis patients, and our results indicate that, as a group, sarcoidosis patients have lower mean total lymphocyte counts and lower $T$ cell counts than the control series in agreement with other reports. We found no difference between B cells in the sarcoidosis and control groups. The quantitative abnormalities detected did not correlate with any of the clinical parameters which were investigated-stage of disease, duration of the disease, treatment regime, and activity of disease-and there was a considerable overlap between the results obtained in sarcoidosis patients and the controls. Our results indicate that these investigations are of little value in the management of sarcoidosis patients.
\end{abstract}

In vitro investigations of immunological reactivity in sarcoidosis have revealed both quantitative and qualitative abnormalities in the immune system. Lymphopenia has been reported as a feature in a high percentage of patients (Hoffbrand, 1968), and the mean total lymphocyte count of groups of sarcoidosis patients has been shown to be significantly lower than that of control groups (Hedfors, Holm, and Pettersson, 1974; Ramachandar et al., 1975). Studies on lymphocyte subpopulations have shown that the lymphopenia is due to a selective reduction in thymus derived lymphocytes ( $T$ cells) responsible for cellular immune responses while 'Bursa' derived lymphocytes (B cells) responsible for humoral immunity have been found to be present in normal or increased numbers (Hedfors et al., 1974; Mangi et al., 1974a; Ramachandar et al., 1975). Techniques available for identifying these subpopulations include the sheep red cell rosette technique for T cells (Jondal, Holm, and Wigzell,

'Present address: Division of Pulmonary Medicine, Department of Medicine, Stanford University Medical Center, Stanford, California
1972; Wybran, Carr, and Fundenberg, 1972) and a fluorescent antibody technique for the identification of immunoglobulin bearing cells (B cells) (Papamichail, Brown, and Holborow, 1971; Brown and Greaves, 1974).

We report here a quantitative analysis of $T$ and $B$ cell populations in a group of 52 patients with sarcoidosis. Findings have been correlated with the clinical features of these patients to determine the value of these investigations in a clinical context.

\section{MATERIAL AND METHODS}

PATIENTS AND CONTROLS The series consisted of 52 patients (mean age 31 years) with sarcoidosis and 34 healthy young adults (mean age 25 years) as controls. The diagnosis of sarcoidosis was confirmed histologically in all patients. All have been examined clinically, radiologically, and with pulmonary function tests within 12 months of this study.

The patients were grouped according to the following clinical criteria: stage, activity, dura- 
tion of disease process, and treatment programme (Table I). The stage of the disease depended on the chest radiograph: stage I had bilateral hilar lymphadenopathy (BHL), stage II had BHL and pulmonary infiltrates, and stage III had pulmonary infiltrates with or without fibrosis. Patients with a clear chest radiograph were classified as extrathoracic sarcoidosis (stage 0). Disease was considered to be active if its onset was within the preceding 12 months, if new clinical symptoms or signs had appeared, if pulmonary infiltrates showed either no change or progression of lesions, or if pulmonary function tests were unchanged or had deteriorated within the preceding year. A patient was included in the 'treated' group if he or she was currently receiving prednisone or had received prednisone for more than three weeks within the preceding six months.

T A B L E I COMPARISON OF SUBGROUPS WITHIN SARCOID GROUP

\begin{tabular}{lllll}
\hline 1. Stage I disease & $(26)$ & $v$ & Stages II, III, and 0 & $(26)$ \\
2. 'Active' disease & $(42)$ & $v$ & 'Inactive' disease & $(10)$ \\
3. Patients on treatment & $(27)$ & $v$ & Patients off treatment & $(25)$ \\
4. Duration < 2 years & (33) & $v$ Duration >2 years & (19)
\end{tabular}

The number of patients in each subgroup is shown in parentheses.

\section{INVESTIGATIONS}

Total lymphocyte count This was derived from the total white cell count (obtained in Coulter F machine) and a differential white cell count.

Lymphocyte separation Fresh heparinized blood was layered on a Ficoll Hypaque density gradient and spun in a centrifuge for $20 \mathrm{~min}$ at $1500 \mathrm{rpm}$. Cells aspirated from the interface were washed in Hanks' solution three times. A drop was diluted in $2 \%$ glacial acetic acid for counting and cells were resuspended at a final concentration of $2.5 \times 10^{6} / \mathrm{ml}$ in Hanks' solution.

Labelling of $\mathrm{I} g$ bearing cells Lymphocytes preparea as outlined above were centrifuged. The button was resuspended in 5 drops of $1 / 5$ solution fluorescein conjugated polyvalent antiserum to human immunoglobulin $\mathrm{G}, \mathrm{A}$, and $\mathrm{M}$ (Wellcome). Cells were incubated for 30 minutes at $4^{\circ} \mathrm{C}$, washed three times, and examined with a Zeiss standard Universal microscope fitted with a mercury superpressure lamp as ultraviolet (UV) source. Primary filters BG12 and BG38 and a secondary filter with a cut-off at $5300 \mathrm{Av}$ were used. Each field was examined under UV light and ordinary light alternately to obtain the percentage

labelled cells.
Sheep red blood cell rosette test Sheep red blood $\frac{\overline{\frac{}{5}}}{\overline{\frac{5}{7}}}$ cells (SRBC) were washed three times in Hanks' $\stackrel{\mathbb{Q}}{\varrho}$ solution and adjusted to a final concentration of $0.5 \%\left(1 \times 10^{*} / \mathrm{ml}\right)$. To $0.2 \mathrm{ml}$ aliquots of lympho- $\vec{O}$ cytes (containing $2.5 \times 10^{6} / \mathrm{ml}$ ) were added $0.2 \mathrm{ml} \stackrel{\circ}{\circ}$ SRBC suspension and $10 \%$ fetal calf serum. Cells $\vec{\omega}$ were mixed, centrifuged at $50 \mathrm{~g}$ for 10 minutes, $\stackrel{\Omega}{\rightleftharpoons}$ and incubated at $4^{\circ} \mathrm{C}$ overnight. Immediately $\vec{x}$ before counting cells were gently resuspended by shaking. All lymphocytes binding three or more SRBC were considered positive. Two hundred o lymphocytes were counted and a percentage was $\mathrm{S}$ obtained (Jondal et al., 1972).

Null cells The absolute number of cells in each $\vec{\square}$ preparation from each patient which failed to $\mathbb{D}$ react with SRBC or anti-immunoglobulin antisera $\stackrel{\oplus}{3}$ was derived by subtracting the combined totals of $\frac{\vec{\sigma}}{\mathrm{O}}$ $\mathrm{T}$ and $\mathrm{B}$ lymphocytes from the total lymphocyte $\stackrel{\mathbb{D}}{?}$ count.

Statistics Statistical evaluation of the results was. carried out with the use of Student's $t$ test. Mean values are expressed \pm standard error of the mean.

\section{RESULTS}

The results of the sarcoidosis series and controls are shown in Table II.

Total lymphocyte count The mean total lympho-o cyte count in the sarcoidosis patients was $1606 /$ $\mathrm{mm}^{3} \pm 90$ (SE). This was significantly lower than을 the mean value obtained in the control series of $\underset{x}{0}$ $2234 / \mathrm{mm}^{3} \pm 123$ (SE) $(\mathrm{P}<0.001)$.

$T$ cell count The mean and standard error obtained in the sarcoidosis group for $T$ cell count $\frac{O}{3}$ was $1062 / \mathrm{mm}^{3} \pm 71$. This again was significantly lower than that seen in the control group, $1650 / \frac{}{2}$ $\mathrm{mm}^{3} \pm 92(\mathrm{P}<0.001)$.

$B$ cell count The mean and standard error for B cell counts in both groups was $263 / \mathrm{mm}^{3} \pm 19$ o (sarcoidosis patients) and $311 / \mathrm{mm}^{3} \pm 26$ (controls). N The difference was not statistically significant.

Percentage values for all cell counts The meano percentage values obtained for B and T cell countso are shown in Table II. The mean total percentage of cells identified as either B or T cells in the? sarcoid group was $81.7 \%$ and in the control group $88.4 \%$. Although the percentage of cells noto identified as either B or $T$ cells (null cells) was higher in the sarcoid group than in the controls, $\mathbb{\mathbb { D }}_{\mathbb{Q}}$ the mean and standard error of the absoluteog 
T A B L E I I

RESULTS OBTAINED FOR TOTAL LYMPHOCYTE COUNT AND T AND B CELL COUNTS IN SARCOIDOSIS PATIENTS AND CONTROLS EXPRESSED AS MEAN AND SE OF MEAN AND AS MEAN \% VALUE FOR T AND B CELLS

\begin{tabular}{|c|c|c|c|c|c|c|}
\hline & & \multirow{2}{*}{$\begin{array}{c}\text { Total Lymphocyte } \\
\text { Count } \\
(\text { mean } \pm \text { SE) }\end{array}$} & \multicolumn{2}{|c|}{ T Cells } & \multicolumn{2}{|c|}{ B Cells } \\
\hline & & & $\underset{(m e a n \pm \mathbf{S E})}{\text { Number }}$ & Mean \% & $\underset{(\text { mean } \pm \text { SE) }}{\text { Number }}$ & Mean $\%$ \\
\hline $\begin{array}{l}\text { Sarcoidosis patients } \\
\text { Controls } \\
\text { Significance }\end{array}$ & $\begin{array}{l}\text { (52) } \\
\text { (34) }\end{array}$ & $\begin{array}{l}1606 \pm \quad 90 \\
2234 \pm 123 \\
P<0.001\end{array}$ & $\begin{array}{l}1062 \pm 71 \\
1650 \pm 92 \\
P<0.001\end{array}$ & $\begin{array}{l}65 \cdot 4 \\
74 \cdot 4\end{array}$ & $\begin{array}{c}263 \pm 19 \\
311 \pm 26 \\
\text { N.S. }\end{array}$ & $\begin{array}{l}16 \cdot 3 \\
14 \cdot 0\end{array}$ \\
\hline
\end{tabular}

T A B L E I I I

RESULTS OBTAINED IN DIFFERENT GROUPS (EXPRESSED AS MEAN \pm SE) ${ }^{2}$

\begin{tabular}{|c|c|c|c|}
\hline . & $\begin{array}{c}\text { Total Lymphocyte } \\
\text { Count }\end{array}$ & $\begin{array}{l}\text { T Cell } \\
\text { Count }\end{array}$ & $\begin{array}{l}\text { B Cell } \\
\text { Count }\end{array}$ \\
\hline Stage: I & $\begin{array}{l}1650 \pm 146 \\
1563 \pm 107\end{array}$ & $\begin{array}{r}1126 \pm 114 \\
982 \pm 83\end{array}$ & $\begin{array}{l}249 \pm 28 \\
276 \pm 27\end{array}$ \\
\hline $\begin{array}{l}\text { Activity: Active } \\
\text { Inactive }\end{array}$ & $\begin{array}{l}1571 \pm 99 \\
1754 \pm 216\end{array}$ & $\begin{array}{l}1004 \pm \quad 76 \\
1284 \pm 166\end{array}$ & $\begin{array}{l}266 \pm 21 \\
252 \pm 49\end{array}$ \\
\hline Duration: $\begin{aligned} & <2 \mathrm{yr} \\
& >2 \mathrm{yr}\end{aligned}$ & $\begin{array}{l}1571 \pm 107 \\
1668 \pm 163\end{array}$ & $\begin{array}{r}996 \pm 80 \\
1166 \pm 137\end{array}$ & $\begin{array}{l}266 \pm 22 \\
258 \pm 36\end{array}$ \\
\hline $\begin{aligned} & \text { Treatment: } \text { On } \\
& \text { Off }\end{aligned}$ & $\begin{array}{l}1531 \pm 105 \\
1688 \pm 148\end{array}$ & $\begin{array}{r}976 \pm \quad 80 \\
1139 \pm 118\end{array}$ & $\begin{array}{l}278 \pm 27 \\
248 \pm 27\end{array}$ \\
\hline
\end{tabular}

${ }^{1}$ Differences between results within subgroups not statistically significant.

numbers of these cells showed no significant difference between the two groups (sarcoidosis patients $293 / \mathrm{mm}^{3} \pm 29$ and controls $272 / \mathrm{mm}^{3} \pm 40$ ).

Subgroup analysis No significant difference was observed in the results obtained within any of the clinical subgroups of sarcoidosis patients analysed for total lymphocyte count, $T$ cell or B cell counts. The results obtained for each clinical subgroup expressed as mean and standard error are shown in Table III.

\section{DISCUSSION}

The results of this study show that sarcoidosis patients as a group have a lower mean total lymphocyte count than normal controls. They also have a significantly lower $T$ cell count while there was no significant difference in the absolute numbers of $B$ cells or null cells between the two groups. Analysis of lymphocyte subpopulations in the clinical subgroups shows that there is no significant difference in the groups selected for stage, activity, treatment programme or duration of the disease.

These results confirm those of several other workers (Hoffbrand, 1968; Hedfors et al., 1974; Ramachandar et al., 1975). There appears to be general agreement on the reduced total lymphocyte count and $T$ cell count in sarcoidosis patients but an elevated mean $B$ cell count has been pre- viously reported (Ramachandar et al., 1975) although we did not find this in the present study in agreement with other reports (Hedfors et al., 1974; Mangi et al., 1974a). Absolute numbers of cells which fail to react with SRBC and antiimmunoglobulin antisera (null cells) showed no significant difference between the sarcoidosis group and the controls in this study. The nature of these cells is not certain. Undoubtedly some represent contaminating monocytes. The combined percentage total for $B$ and $T$ cells in the present survey was $81.7 \%$ for the sarcoidosis group and $88.4 \%$ for the control group. Other reports show varying figures for the combined total of $\mathrm{T}$ and $\mathrm{B}$ cells from $71 \%$ to $108 \%$ (Mangi et al., 1974a; Ramachandar et al., 1975). This underlines the importance of technical factors in different surveys which make direct comparison difficult. Other problems encountered on comparing different studies on sarcoidosis patients include the variability of the disease process under investigation both within a country and between countries (Hall et al., 1969; Siltzbach et al., 1974).

The failure to demonstrate differences between sarcoidosis patients selected for stage, activity, treatment regime, and duration of the disease process is at variance with some previous reports. A lower total lymphocyte count was found in patients with long-standing disease than in those 
of recent onset (Hoffbrand, 1968; Hedfors et al., 1974). A lower T cell count was found in patients receiving corticosteroid therapy than in those not receiving such therapy (Mangi et al., 1974a). However, other studies have failed to show a correlation between quantitative abnormalities of the lymphocyte subpopulations and disease activity (Hedfors, 1975; Ramachandar et al., 1975).

The significance of the observed abnormalities remains to be elucidated. The reduced $T$ cell count in sarcoidosis patients may reflect decreased production or increased 'utilization'. Circulating inhibitors have been identified in sarcoidosis patients which reduced lymphocyte responsiveness to mitogens (Belcher, Carney, and Nankervis, 1974; Mangi, Dwyer, and Kantor, 1974b). A similar mechanism may be involved in the quantitative reduction in $T$ cells. It has been suggested that lymph node involvement by the disease process may impair recirculation of $T$ lymphocytes contributing to the lower $T$ cell counts (Ramachandar et al., 1975).

The results of the present study and others indicate that these investigations are of limited value in the management of individual patients with sarcoidosis. The observed abnormalities in this study fail to correlate with the clinical features of sarcoidosis in groups of patients. The value of sequential analysis in individual patients remains to be assessed.

We wish to thank the Medical Research Council of Ireland for financial support and Miss J. Woods for statistical advice, and Mrs. M. Melinn and Miss $O$. Crowley for technical assistance.

\section{REFERENCES}

Belcher, R. W., Carney, J. F., and Nankervis, G. A. (1974). Effect of sera from patients with sarcoidosis on in vitro lymphocyte response. International Archives of Allergy and Applied Immunology, 46, 183.

Brown, G. and Greaves, M. F. (1974). Enumeration of absolute numbers of $T$ and $B$ lymphocytes in human blood. Scandinavian Journal of Immun-
ology, 3, 161 .

Hall, G., Naish, P., Sharma, O. P., Doe, W., and $\frac{\bar{\sigma}}{\bar{\omega}}$ James D. G. (1969). The epidemiology of sar-

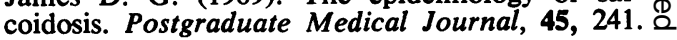

Hedfors, E. (1975). Influence of steroid treatment on lymphocyte response in sarcoidosis. Clinical $\vec{O}$ Immunology and Immunopathology, 4, 96.

Hedfors, E., Holm, G., and Pettersson, D. (1974). $\overrightarrow{\vec{\omega}}$ Lymphocyte subpopulations in sarcoidosis. Clinical and Experimental Immunology, 17, 219.

Hoffbrand, B. I. (1968). Occurrence and significance of lymphopenia in sarcoidosis. American Review of Respiratory Diseases, 98, 107.

Jondal, M., Holm, G., and Wigzell, H. (1972). Surface markers on human $T$ and $B$ lymphocytes. I. A G large population of lymphocytes forming non-음 immune rosettes with sheep red blood cells. Journal of Experimental Medicine, 136, 207.

Mangi, R. J., Dwyer, J. M., Gee, B., and Kantor, F. S. (1974a). The immunological competence of $\Phi$ subjects with sarcoidosis. Clinical and Experimental Immunology, 18, 505.

Mangi, R. J., Dwyer, J. M., and Kantor, F. S. (1974b). $\vec{\bullet}$ The effect of plasma upon lymphocyte response in vitro. Demonstration of a humoral inhibitor. in patients with sarcoidosis. Clinical and Experimental Immunology, 18, 519.

Papamichail, M., Brown, J. C. and Holborow, E. J.ב (1971). Immunoglobulins on the surface of humano lymphocytes. Lancet, $2,850$.

Ramachandar, K., Douglas, S. D., Siltzbach, L. E., $\stackrel{\mathbb{Q}}{\circ}$ and Taub, R. N. (1975). Peripheral blood lym- $=\overrightarrow{0}$ phocyte subpopulations in sarcoidosis. Cellular Immunology, 16, 422.

Siltzbach, L. E., James, D. G., Neville, E., Turiaf, J. Battesti, J. P., Sharma, O. P., Hosoda, Y., Mikami, R., and Odaka, M. (1974). Course andF prognosis of sarcoidosis around the world. Ameri-음 can Journal of Medicine, 57, 847.

Wybran, J., Carr, M. C., and Fundenberg, H. H. (1972). The human rosette forming cell as marker for a population of thymus derived cells $\stackrel{\rho}{\Omega}$ J. clin. Invest., 51, 2527.

Requests for reprints to: Dr. H. McLaughlin, Depart ment of Pathology, University College, Dublin 2. N 